\title{
A MARÓTÁRCSÁS KOTRÓGÉPEK ÜZEMELTETÉSE NEHEZEN JÖVESZTHETŐ BEÁGYAZÓDÁSOK MEGJELENÉSEINEK ESETÉBEN
}

\section{THE OPERATING OF BUCKET WHEEL EXCAVATORS WHEN OCCURE INCLUSIONS WITH EXCESSIVE MINING RESISTANCE}

\author{
András József ${ }^{1}$, Kovács József ${ }^{2}$ \\ ${ }^{1}$ Petrozsényi Egyetem, Gépész és Villamosmérnöki Kar, Gépész, Ipari és Szállítás- \\ mérnöki Tanszék), Cím: 332006, Románia, Petrozsény, Universității utca, 20 szám; \\ Telefon / Fax: +40722262067, iosif.andras@gmail.com \\ ${ }^{2}$ Petrozsényi Egyetem, Gépész és Villamosmérnöki Kar, Gépész, Ipari és Szállítás- \\ mérnöki Tanszék), Cím: 332006, Románia, Petrozsény, Universității utca, 20 szám; \\ Telefon / Fax:0723193455, kovacsi@mail.com
}

\begin{abstract}
The Bucket Wheel Excavator (BWE) is the main harvesting equipment used in open pit lignite or brown coal open pit mines worldwide. Despite the continuous increase of size, productivity and technical sophistication in the past decades, they are not adapted to the changes of operating environment. In this respect, the more and more frequent escalation of hard inclusions - in terms of layers, boulders and other forms - revealed a consistent non-adaptation of BWE-s to face this challenge. The actual paper, inspired by the research project RFCR-CT-2015-00003-BEWEXMIN „Bucket wheel excavators operating under difficult mining conditions including un-mineable inclusions and geological structures with excessive mining resistance" is dealing with the preliminary considerations and results in view to contribute to solve this problem.
\end{abstract}

Keywords: excavator, lignite, mining, excavatability, hard intrusions

\section{Összefoglalás}

A külszíni lignit bányászatban, úgy a szén kitermelésére, mint a fedő kőzet eltávolítására, már hagyományos technológia a marótárcsás kotrógépek használata. Az utóbbi időben, viszont, az európai országok külszíni lignit bányáiban a természetes - földtani, kőzeti - környezet folytonosan romlik. Egyre gyakoribb a nehezen jöveszthető beágyazódások megjelenése, amelyek előbukkanása művelési szüneteléseket, meghibásodásokat, magas energiafogyasztást, csökkentett termelékenységet és végső soron magas önköltséget okoznak. A létező marótárcsás kotrógépek nem alkalmasak az ilyen jellegü, megváltozott körülményekben való üzemeltetésre. A jelen dolgozat ezt a jelenséget tárgyalja, a RFCR-CT2015-00003-BEWEXMIN európai projekt keretében végzett kutatás eredményeinek tükrében.

Kulcsszavak: kotrógép, lignit, bányászat, jöveszthetőség, beágyazódások. 


\section{Bevezetés}

A külszíni lignit bányászatban, úgy a szén kitermelésére, mint a fedő kőzet eltávolítására alkalmazott hagyományos technológia, főleg Európában, a marótárcsás kotrógépek használatán alapszik.

Az utóbbi időben, viszont, több Európai országok külszíni lignit bányáiban a természetes - földtani, kőzeti - környezet folytonosan romlik.

Egyre gyakoribb a nehezen jöveszthető beágyazódások megjelenése, amelyek előbukkanását művelési szünetelések, meghibásodások, magas energiafogyasztás, csökkentett termelékenység és végül magas önköltség-kíséri.

A létező marótárcsás kotrógépek nem alkalmasak az ilyen körülmények között való üzemeltetésre.

Ennek a fő oka az, hogy a marótárcsás kotrógépet eredetileg ömlesztett állapotban levő anyagok rakodására tervezték.

A marótárcsás kotrógépek jövesztésre való adaptációja a XX. század 50-es éveiben történt, akkor alapozták meg a tervezési, gyártási és üzemeltetési szabványokat, előbb Németországban, majd ezt követően más országokban. [1], [2].

Ezek a gépek az elején általában könynyen jöveszthető kőzetben, lignitben vagy barnaszénben müködtek. Később, ezeknek a gépeknek a müködtetésével nyert tapasztalat alapján, ezek más országokban is elterjedtek, mint például Lengyelországban, Csehszlovákiában és Romániában.

Itt viszont különböző, az eredetitöl eltérő kőzeti környezetben alkalmazták.

Többek között, gondokat okoztak a meddőkőzet vagy a szén jövesztési erő- és energiaigény-tényezők értékei, ezeknek változékonysága, mint pld. a kisebb telepvastagság stb.

$\mathrm{Az}$ átvett tervezési szabványok hiányosak voltak, föleg az új környezetben fellépő dinamikus jellegü igénybevétellel kapcsolatosan, a dinamikus igénybevételt helyettesítő statikus igénybevétel megállapítását illetően. [3].

Még a legújabb, Európa-szerte alkalmazott szabvány is (DIN 22261), [7], a régi dinamikai együtthatókat alkalmazza, pedig közben a gyakorlat kimutatta, hogy ezek valós értéke sokkal magasabb.

Ezért, az említett BEWEXMIN projekt fö célja az, hogy olyan megoldásokat javasoljon és dolgozzon ki, hogy az előbbiekben említett, nem kívánt jelenségek következményeit vagy ezeknek gyakoriságát megelőzzék illetve csökkentsék.

Ezt egyrészt úgy lehet elérni, hogy a létező kotrógépeket honosítsák ezeknek az újonnan keletkezett körülményeknek megfelelően és ezeket az eredményeket az új gépek tervezéséhez felhasználják. [4], [5], [6]

Másodsorban egy olyan folytonos ellenőrzési rendszer kidolgozása és létrehozása kívánatos, amelyik az érzékeny szerkezeti egységekben létrejött veszélyes terheléseket (az üzemeltetési körülmények figyelembevételével) és a bekövetkezendő veszélyt is elöre jelezze.

A kutatómunkát három irányba terveztük, éspedig: azon követelmények megállapítása, amelyeknek a kotrógép felépítése eleget kell tegyen, annak érdekében, hogy a dinamikus terhelés minimális legyen.

Erre alapozva, további két irány rajzolódott ki, éspedig:

- monitoring rendszer kidolgozása;

- a fejtés reálidőben való ellenőrzése, különböző geofizikai módszerek bevonásával, a beágyazódások előzetes felismerésére.

\section{Az elvégzett kutatások rövid bemutatása}

Az utóbbi időben több Európai országban, a külszíni lignit bányákban gyakori jelenség a lignittelepekben vagy a telepet fedő illetve a telepek közötti meddőkőzetben a nehezen jöveszthető beágyazódások megjelenése. 
Ezek a jelenségek a marótárcsás kotrógépek üzemeltetésében folytonosan komoly gondokat okoznak.

Eleinte ilyen jelenségek nagyon ritkán keletkeztek, és csak bizonyos külszíni bányákban, egy-egy országban.

Ezért, ennek a jelenségeknek a kutatása is csökkentett mértékben történt, az adott bánya sajátos szükségleteire fokuszálva, az eredményeket pedig ritkán hozták nyilvánosságra.

A szakirodalom inkább a kotrógép meghajtó rendszerének a dinamikai (túl) terhelésével foglalkozott. Általában, az említett irodalomban, a helyi kőzeti környezet leírása elég szegényes, úgy hogy nehéz összefüggéseket megállapítani a kőzeti környezet és a gondokat okozó túlterhelés között.

Egy másik irány az eddigi kutatásokban arra összpontosult, hogy a meghajtó rendszert megóvják a dinamikus hatások okozta károsodástól, és így különböző hidraulikus biztonsági tengelykapcsolók alkalmazását vezették be, a meríték-fejlesztés mellett. [7]

$\mathrm{Az}$ eredmény sajnos nem volt nagyon biztató, arra a következtetésre jutottunk, hogy nem lehet egy kotrógépet úgy beállítani, hogy az minden környezetnek megfelelö (univerzális) legyen, biztonság, hibamentesség és termelékenység szempontjából.

$\mathrm{Az}$ egyedi (nem rétegszerü) beágyazódások mérete a meríték térfogatához viszonyítva nagy befolyást gyakorol az okozott károsodások súlyosságára és terjedelmére, például a nagy térfogatú merítékekkel ellátott kotrógépek esetében, (4 $\mathrm{m}^{3}$ és annál nagyobb), az ennél kisebb beágyazódást a meriték kiássa a frontból és ez tovább kerül, a szállító rendszerre és ott okoz majd károsodásokat.

Ha a beágyazódás mérete nagyobb, mint a merítéké, akkor a bontófogakkal való ütközés okoz dinamikus igénybevételt a jövesztő rendszerre.

Mivelhogy Németországban inkább a nagy térfogatú meritékes kotrógépeket alkalmazzák, a német kutatok főleg a szállító- szalagra került beágyazódás-darabokat észlelő érzékelőkkel foglalkoztak.

Bár a használható érzékelők jól ismertek és kifejlesztettek, mégis az elért eredmények ebben az esetben is szerények, a befektetéshez viszonyítva, főleg az elemző és adatkezelő szoftver szempontjából.

Egy összefoglalót nyújt ebben a témakörben a Németországban végzett tanulmányokról szóló [5] dolgozat.

$\mathrm{Az}$ eddigi tanulmányok hátránya az, hogy hiányzott a kőzeti környezet párhuzamos elemzése, tehát nem lehetett összefüggéseket levezetni az ok és következmény között.

A másik nehezítő tényező az érzékelők számának és elhelyezésének meghatározása, úgy hogy a gém elemeinek igénybevételi állapotát a rendszer valósan tükrözze; ezek által szolgáltatott információ, hogy ez hogyan legyen kezelve.

Az efféle kísérleti megközelítés mellett, elméleti megközelítések is szóba jöttek, éspedig olyan elméleti modellek kidolgozására, amelyek leírják a változó, vagy pulzáló külső terhelésnek a hatását a kotrógép jövesztő- tartó szerkezetének a viselkedésére.

A gerjesztő pulzáló erő időbeli változását a két rugalmas-képlékeny test ütközésének modellje alapján vezették le. [6].

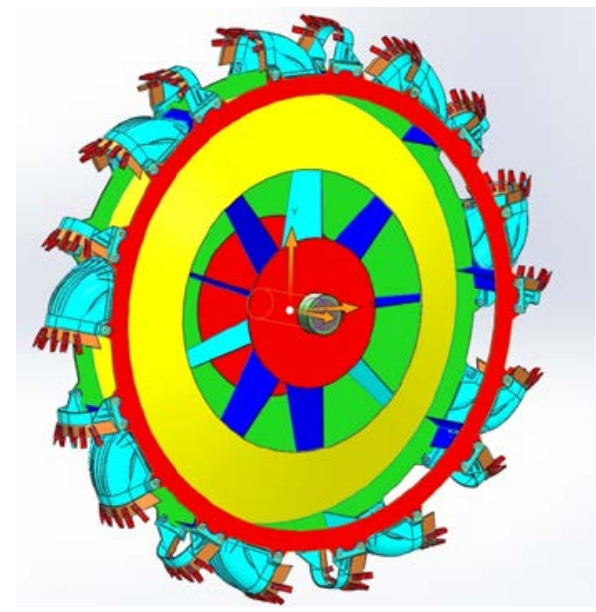

1. ábra. A kotrógép marótárcsájának 3D modellje 

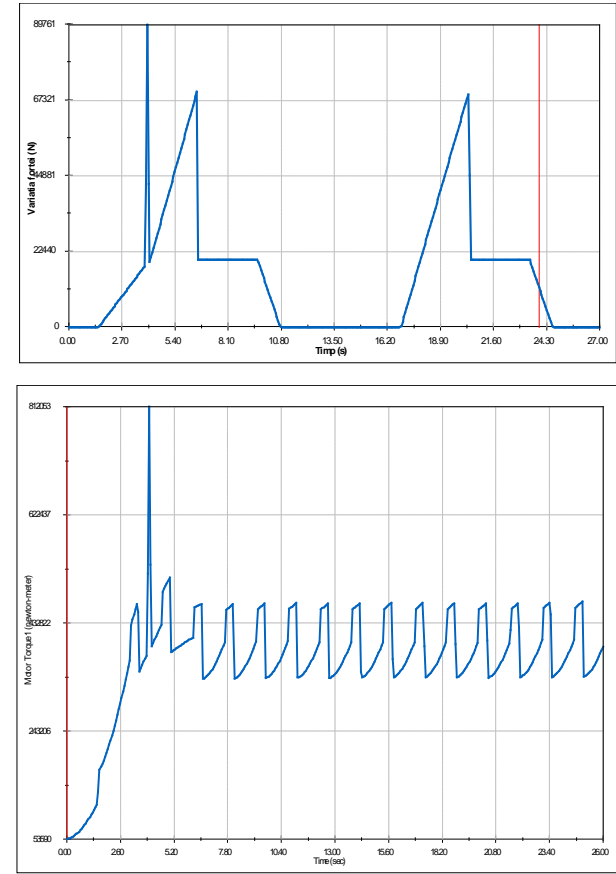

Ezen nyílt kérdések megoldását keresve, a petrozsényi csoportunk kidolgozott egy marótárcsa modellt, (1. ábra) amelyen szimulációt végeztünk és így próbáltuk a pulzáló erő befolyását a hajtónyomatékra szemléltetni (2. ábra).

Tovább, egy gém modellen annak rezgéseinek amplitúdóját és frekvencia spektrumát tanulmányoztuk (3. ábra).

Közben, több külszíni bányában müködő kotrógép gém elemeire szereltünk igénybevétel érzékelöket, amelyek a folytonos mérés eredményeit távközlési rendszer segítségével közvetítették és regisztrálták (4. ábra).

Mivel az igénybevétel érzékelők kényes módszertani problémákat okoztak, gyorsulási érzékelőket is szereltünk a rendszerbe.

A merések összevont eredményeinek értelmezése még folyamatban van, de elözetes eredmények elfogadható összhangban vannak a modell által szerzett eredményekkel.

2. ábra. Az pulzáló erő időbeli változásának modellje (fent) és a meghajtó nyomatékra gyakorolt hatás (lent)

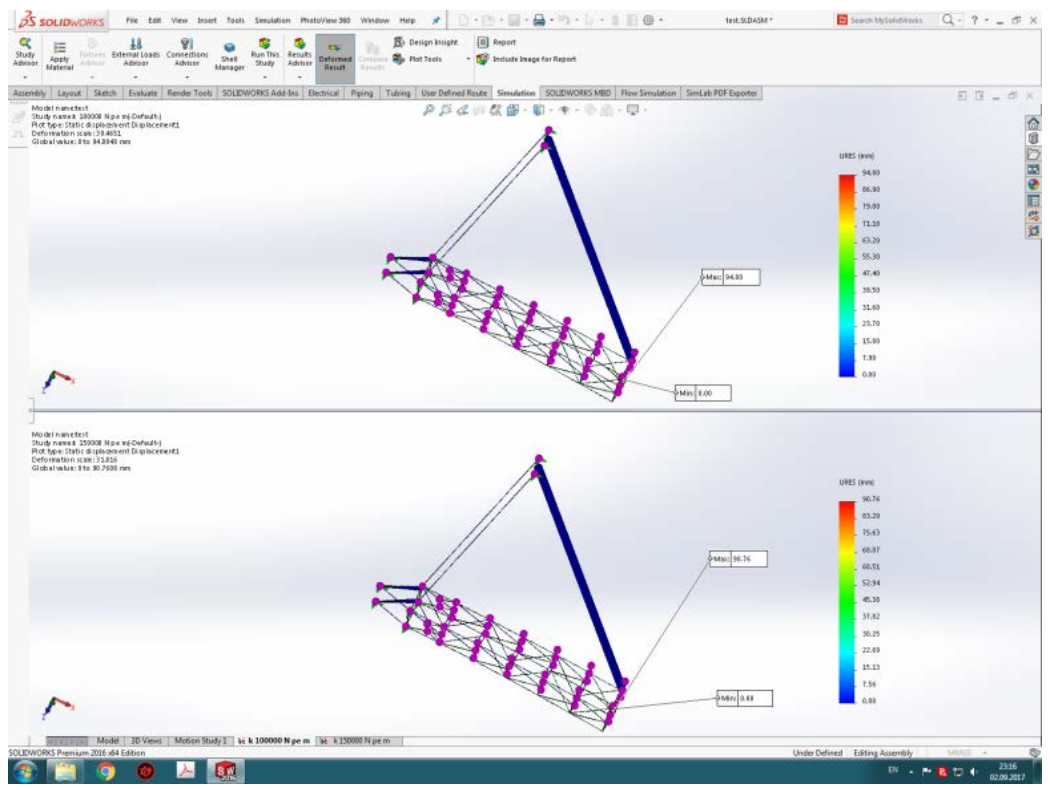

3. ábra. A gém alakváltozásának szimulációja dinamikus hatások által 


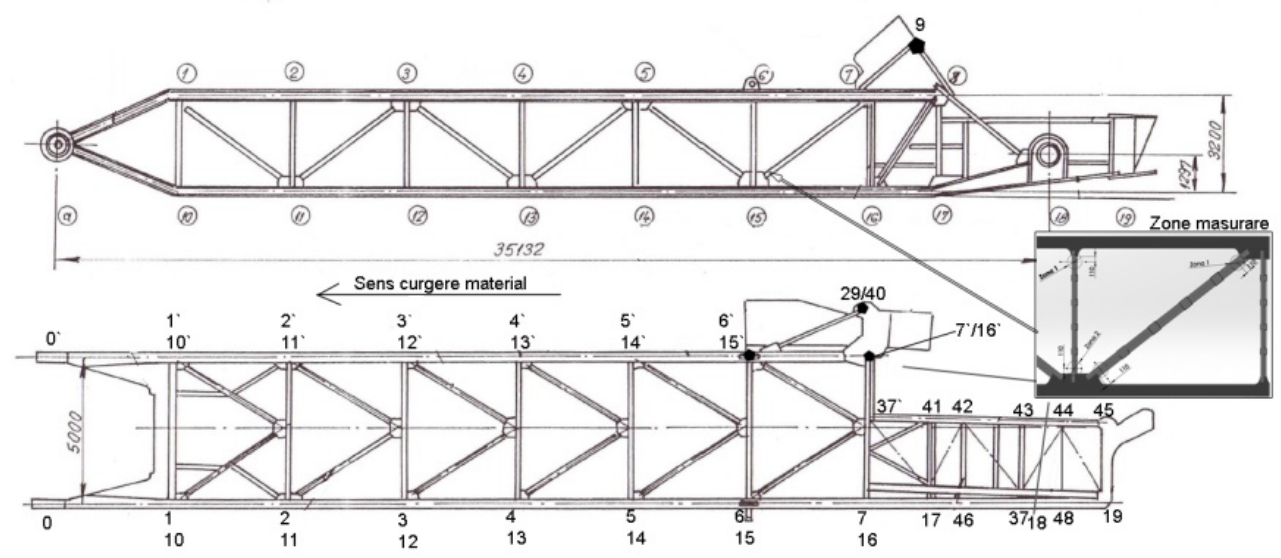

4. ábra. A kotrógép-gémre elhelyezett érzékelők a monitoring rendszerhez

\section{Eredmények}

$\mathrm{Az}$ eddig végzett mérések kimutatták, hogy az igénybevétel rezgéstípusú és változékony jelben két komponens tevődik össze.

Az egyik a marótárcsa és a gép merev tömegeinek a saját rezgése, a másik pedig a jövesztési erő, illetve az egyéb dinamikus hatások által gerjesztett rezgés.

Ezeknek közeli a frekvencia spektrumuk, ezért nehezen különíthető el a különböző gerjesztési rezgésképből az, amelyik a jövesztési erő változásából ered. Ennek a kérdésnek a megoldása a projektnek egy másik fontos célja.

A kutatások egy másik iránya az, hogy a kotrógép működési (üzemelési) paramétereit, a szerkezet dinamikai tulajdonságait és a kőzeti környezet tulajdonságait összevonva a kritikus pontokban meg lehessen becsülni a reális terhelés -igénybevétel értékét.

Ennek eredménye egyrészt a létező kotrógépmodellek adaptációja a nehezen jöveszthető beágyazódásokat tartalmazó kőzetekben való alkalmazásra, másrészt új szabványokat és módszereket kidolgozni, amelyet egy új kotrógép-nemzedék tervezéséhez alkalmazzák.

$\mathrm{Az}$ új monitoring rendszer kifejlesztése nem csak a közvetlen károsodási veszély észlelését és kiküszöbölését szolgálja, ha- nem a szerkezeti elemek kifáradási szintjének az ismeretét, és a gép megmaradt üzemeltetési időtartamának a becslését is.

\section{Következtetések}

Az eddig, az említett 3 irányban elvégzett kutatások a következőket mutatták ki:

Abban az irányban, amely azzal foglalkozott, hogy a váratlanul megjelent beágyazódásokat időben felismerjék, illetve azoknak létezését reálidőben jelezzék úgy, hogy a marótárcsa és a beágyazódás közötti impaktus elkerülhető legyen, több partner külszíni fejtésekben szándékosan különböző talajokban beépített beágyazásoknak az anyakőzettől eltérő tulajdonságait vizsgálták különböző geofizikai eszközökkel. Az eddigi eredmények, például, a Husnicioara-i homokkő esetében nem mutattak észlelhető és felhasználható eredményeket.

A másik irány vonatkozásában, amelyik azzal foglalkozik, hogy milyen hatása van egy váratlan vágóerő hirtelen növekedésének a kotrógép szerkezeteire: bontófog, meriték, marótárcsa, beépített szállítószalag, gém, meghajtás, erőátvitel, stb., ezek megállapításának alapján az említett elemeken olyan szerkezeti adaptációt javasolni, illetve olyan müködési beavatkozást, hogy az eset- 
leges károsodásokat megelőzzék, vagy optimális esetben kiküszöböljék.

Ilyen például egy olyan monitoring rendszer, amely kiszúró szoftver segítségével előre latja a nemkívánt változást, és egy szakértő rendszer segítségével megfelelő döntéshozatalra segíti a gépkezelőt vagy a vezérlő rendszert.

\section{Acknowledgment}

The actual paper is supported by the European Union Research Found for Coal and steel by the research project $\boldsymbol{R F C R}$-CT2015-00003-BEWEXMIN „Bucket wheel excavators operating under difficult mining conditions including unmineable inclusions and geological structures with excessive mining resistance"

\section{Szakirodalmi hivarkozások}

[1] Bošnjak Srđan, Zrnić Nenad, Oguamanam Donatus - On the dynamic modelling of bucket wheel excavators, FME Transactions (2006) 34, 221-226.

[2] Raaz, V., Optimierung der maschinen- mid Verfahrenrechnischen Parameter von Schaufelradbaggem für einen abbau von harteren
Materialen ím Tagebau. Braunkohle in Europa: Innovationen für die Zukunfl; 1. Internationale Konferennnz, 29.Marz bis 1. Aprili 2000. in Freiberg, Tagungsband.

[3] Sümegi, J , Külfejtési marótárcsás kotrógépek jövesztö szerkezetének elméleti vizsgálata és fejlesztése. Doktori értekezés, Miskolci Egyetem, 2002.

[4] DURST W., VOGT V.: Bucket Wheel Excavator. Trans Tech Publications, Clausthal- Zellerfeld, Vol. 7, FRG, 1988

[5] Rodenberg J.F.:Contribution to the Assessment of the Specific Cutting Force for Bucket Wheel Excavators. Continuous Surface Mining. Trans Tech Publications, Vol. 1, No.13/87, Clausthal, Germany, 1987.

[6] Lu Zhong Lin: Beitrag zur Festlegung der Auslegungs- und Betriebsparameter von Schaufelradbaggern durch Untersuchung ihrer Einflüsse auf das effektive Fördervolumen und den Energieverbrauch sowie durch Untersuchung des Entlehrungsvorganges des Fördergutes., Dissertation, TH Aachen, 1983.

[7] DIN 22261-2 Excavators, Stackers and Auxillary Equipment in Brown Coal Open Cut Mines Part 2 Calculation Principals, German Institute for Standardization, 2015. 